\title{
Effective Communication using Visual Media to Communicate Emergency Action Plan based on Dam Failure Model
}

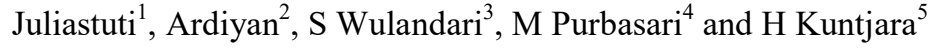 \\ Faculty of Engineering, Universitas Bina Nusantara, Jakarta - Indonesia ${ }^{1}$ \\ Visual Communication Design Department, Universitas Bina Nusantara, Jakarta, \\ Indonesia ${ }^{2,3,4,5}$ \\ $\left\{\right.$ juliastuti@binus.ac.id $\left.{ }^{1}\right\}$
}

\begin{abstract}
Dams provide many benefits for our society such as the supply of drinking and irrigation water, the generation of electric power and flood protection. However, when a dam fails, large quantities of water are suddenly released, creating major flood waves capable of causing damages to downstream areas. Therefore, every dam requires an Emergency Action Plan (EAP) guideline for disaster preparedness. In EAP guidelines, there is emergency management including how to communicate people do the right thing during and after a disaster to have the best chance of survival with as little loss as possible. Effective communication is essential during each phase of emergency management. In the mitigation and preparedness phases, communication helps to exchange and confirm information and efforts to be prepared by appropriate stakeholders and organizations before an event. This paper will describe effective communication using visual communication media concept in leaflet and video to minimize the risk of loss of life and property downstream. Based on the dam failure modeling, the people can know detailed information about the risk area, the property and evacuation procedure to minimize flood hazard.
\end{abstract}

Keywords: Communication, Visual Media, Emergency Action Plan, Dam

\section{Introduction}

Dams provide many benefits for our society such as the supply of drinking and irrigation water, the generation of electric power and flood protection. However, when a dam fails, large quantities of water are suddenly released, creating major flood waves capable of causing damages to downstream areas [1]. Therefore, every dam required an Emergency Action Plan (EAP) guideline for disaster preparedness, which refers to the ICOLD Regulation (International Committee on Large Dam). The purpose of EAP is to minimize the risk of life and property downstream in case of dam failure [2]. The crucial factors in EAP are determined by the level of warning, potentially inundated area and inundation maps, identify situation or event damages and deaths. Evaluate the notice available and identify all jurisdictions, agencies, and individuals who will be involved in the EAP, recognize primary and auxiliary communication system [3] including how to communicate people do the right thing during and after a disaster, so they have the best of surviving with as little loss as possible. Effective 
communication is essential during each phase of emergency management. In the mitigation and preparedness phases, communication helps to exchange and confirm information and efforts to be prepared by appropriate stakeholders and organizations before an event.

\section{Method}

The proposed methodology for dam failure is based on the hydraulic model using the integration of ArcGIS and ZhongXing HY-21. The assumption for the dam failure was if there is a breach in dam body. The breach assumption is mathematical modeling. The possible Dam failure for embankment dam is overtopping, piping/seepage, foundation defects, sliding, cracking and equipment failure [4]. The equations in the software ZhongXing-HY 21 are mass conservation and momentum flow in two dimensions of governing equation of shallow water or 2D Shallow Wave Equation from the Navier-Stokes 3D equations. The equation is (Sinotech Engineering Group, 2011):

The momentum equation in the $\mathrm{x}$-direction:

$$
\begin{gathered}
\frac{\partial p}{\partial t}+\frac{\partial F}{\partial x}\left(\frac{p^{2}}{h}+\frac{g h^{2}}{2}\right)+\frac{\partial}{\partial y}\left(\frac{p q}{h}\right)= \\
-g h \frac{\partial Z_{b}}{\partial x}+\Omega q+\frac{\left(\tau_{x-}^{s} \tau_{x}^{b}\right)}{\rho}+\frac{1}{\rho}\left[\frac{\partial}{\partial x}\left(h \tau_{x x}^{e}\right)+\frac{\partial}{\partial y}\left(h \tau_{x y}^{e}\right)\right]-\frac{h}{\rho} \frac{\partial P_{a}}{\partial_{x}}+S^{P}
\end{gathered}
$$

The momentum equation in $\mathrm{y}$-direction:

$$
\begin{gathered}
\frac{\partial p}{\partial t}+\frac{\partial}{\partial x}\left(\frac{q^{2}}{h}+\frac{g h^{2}}{2}\right)+\frac{\partial}{\partial y}\left(\frac{p q}{h}\right)= \\
-g h \frac{\partial Z_{b}}{\partial y}+\Omega q+\frac{\left(\tau_{y-}^{s} \tau_{y}^{b}\right)}{\rho}+\frac{1}{\rho}\left[\frac{\partial}{\partial x}\left(h \tau_{x y}^{e}\right)+\frac{\partial}{\partial y}\left(h \tau_{y y}^{e}\right)\right]-\frac{h}{\rho} \frac{\partial P_{a}}{\partial_{y}}+S^{q}
\end{gathered}
$$

The conservation equation is:

$$
\frac{\partial Q}{\partial t}+\frac{\partial F}{\partial x}+\frac{\partial G}{\partial y}=\frac{\partial F_{v}}{\partial x}+\frac{\partial G_{v}}{\partial y}+H
$$




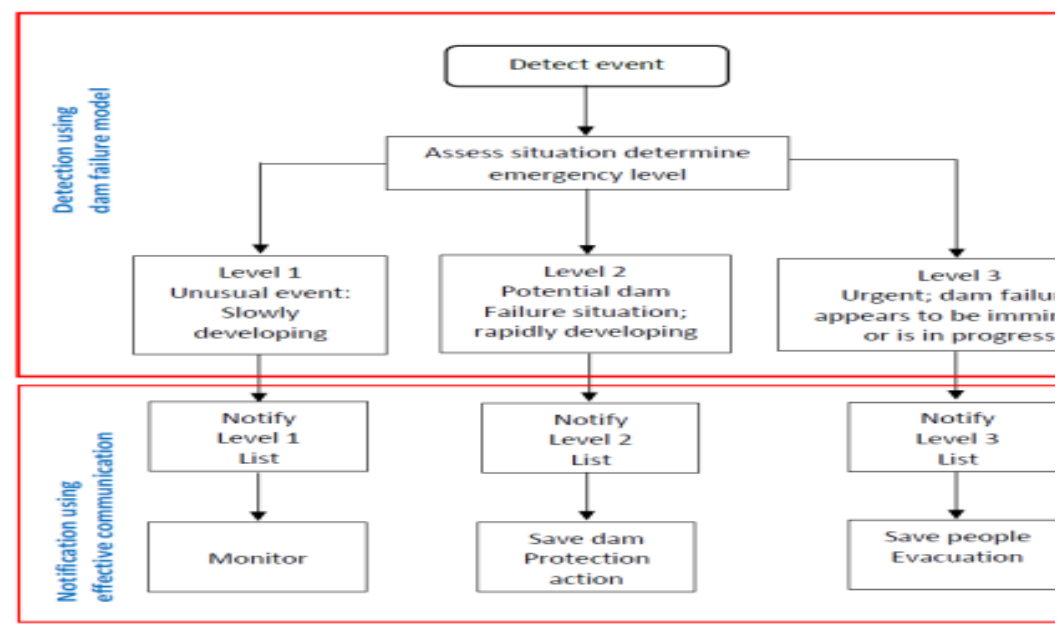

Figure 1. Overview of EAP (Gazioglu, 2014).

\section{Result and discussion}

\section{a. Study Area}

Krisak Dam is located in the Singodutan, Selogiri Village, Wonogiri District, Central Java Province. Currently, this dam is managed by the Central River Region Bengawan Solo [5]. Construction of Krisak Dam is developed in 1943. The type of dam is homogeneous earth dam for irrigation. In downstream is a residential area. The livelihood of the population is primarily farming. The height of Krisak dam is 20 meters, length is 350 meters, and the effective storage is 2,692 million m3. Type of spillway is free to flow ogee, and the length is 33 meters (Figure 2).

\section{b. Inundation Map based on Hydraulic Model}

Based on the hydraulic model and dam break analysis, the location of high-risk inundation if dam break consists of five villages: Nambangan, Gemantar, Singodutan, Kaliancar and Sendangijo (Figure 3). The distance of the affected area and depth of inundation is given in Table 1. Based on the Hazard Classification Guidelines from Directorate General of Water Resources, Public Works and Housing No.257/KPTS/D/2011 [6], the Hazard Classification and inundation zone is shown in Table 1, the hazard classification for Krisak dam is very high and the inundation zone is zone 1 because the risk population is more than 1000 people.
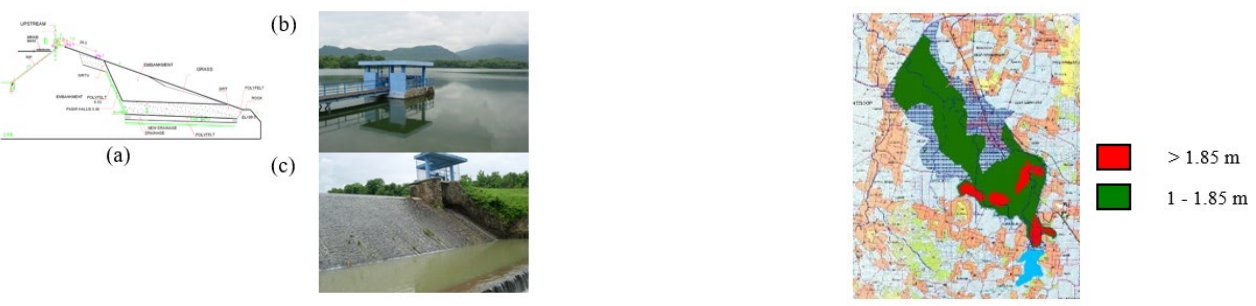
Figure 2. Study area of Krisak Dam; (a) cross section, (b)

Figure 3. Inundation map. intake structure and (c) spillway structure [7].

Table 1.Villages in risk.

\begin{tabular}{lccccc}
\hline \multicolumn{1}{c}{ Village } & $\begin{array}{c}\text { Distance from } \\
\text { Dam }(\mathrm{km})\end{array}$ & Zone & Depth $(\mathrm{m})$ & Class & $\begin{array}{c}\text { Time of Arrival } \\
\text { (minutes) }\end{array}$ \\
\hline Singodutan & 1.45 & 3 & 1,85 & $\mathrm{M}$ & 12 \\
\hline Kaliancar & 1,86 & 3 & 1,54 & $\mathrm{M}$ & 35 \\
\hline Gemantar & 3,69 & 3 & 1,76 & $\mathrm{M}$ & 43 \\
\hline Nambangan & 4.85 & 3 & 1,45 & $\mathrm{M}$ & 52 \\
\hline Sendangijo & 6.36 & 1 & 0,24 & $\mathrm{~L}$ & 60 \\
\hline Singodutan & 1.45 & 3 & 1,85 & $\mathrm{M}$ & 12 \\
\hline
\end{tabular}

To socialize the EAP to the community, they certainly need to know in advance the situation and conditions of the environment where they live, so they understand the importance of EAP, what is essential to prepare, and not lose the orientation when the disaster occurred. Therefore, we need to make a communication media that can convey that information to the public. One of the popular media used by society is the leaflet. It can keep information for a long time and can be read back anytime, anywhere and quickly to produce. It is important to note that to visualize the information in the leaflet should be appropriately done by arranging the layout hierarchical, so the reader can get the point quickly, mainly when the emergency case occurs. Some group of information with bold or big typography used to make emphasis and eye-catcher. In EAP video, the flowing water in animation can be created in how to make the polygonal condition of the scenes, the contour of polygonal 3D model topology as the ground in the scene affects the movement of the water simulation, the 3D model could be assigned as representation of building or rock that passed by the water simulation, therefore, the animator only made the setup for the animation scene and set the trigger for the water simulation in Real Flow software, with this software the computer calculates the water animation precisely. The geographical terrain was developed as a 3D model in the 3D application by the 3D modeler, the texturing process in the video such as the ground texture, building texture, and the water texture is created from unwrapped digital images material. The next process is to set up lighting in the scene with daylight intensity setting as close as possible with the Krisak lighting condition, and the final process to converting polygonal animation into the video is in the rendering process, it is generating photorealistic images that automatically processed by the computer. The photorealistic rendering through computation algorithm by the computer not only to gives visually informative but also needs to be persuasively to the audiences. Developing production 3D model that used in the simulation are precise with accurate among proportion, dimension and measurements. The scene condition can be described as a hub relation nodes diagram. In this case, the scene contents $3 \mathrm{D}$ space that can be the representation of the world, the simulation can be built by adding 3D model as an object representation, single circle emitter that produces particles, the gravity that affects particles horizontally movement and dynamically calculates the collisions between particles. Particle mesh feature converts the particles into the polygonal object, the collision and distance of the particles with another particle could be modified the form of particle mesh similar as blob mesh method. The scene setup above is the simplest to set, the simulation conditions that will be designed as in the real-world condition 
should be planed representatively in software world space, the imitation assets represent any objects characteristic made its behavior as the real-world system [8]. Therefore, in Krisak EAP video which is included water simulation, described the closeness approach with real Krisak area condition. The video also content disaster management, the visual style brought in animation has cartoon style and iconic, for representing the emergency information that should be communicated as communication concepts [9], an icon offers direct message to the audience that potentially across language barriers, faster interaction and recognized quickly $[5]$.

\section{Conclusion}

Risk communication in practice to socialize an Emergency action plan (EAP) if dam failure is difficult at best, requiring a detailed understanding of the population targeted, the methods (channels) most suitable for reaching them, and the types of messages most likely to be received and acted upon. The population must understand the situation and conditions of the potential damage based on dam failure model where they live, what is essential to prepare, and not lose the orientation when the disaster occurred. The communication by visual media in leaflet and video based on local culture is one of the effective communications. The information in the leaflet is contained: title and mandatories, the profile of EAP, equipment need to be prepared, what people must do, who to call in case of an emergency including a map of the location and evacuation routes, the location outside to evacuate and evacuation process. The information EAP Video must have relation to the leaflet. The audio and moving pictures media, whether live shooting or animation show not only the geographical condition but also content that could be more interesting and communicatively to watch for the community. The animation itself used the simulation method, to visualize the water flows when the dam in disaster and give some information on disaster management.

\section{References}

[1] L. W. Tony, Prediction of Embankment Dam Breach Parameters - A literature review and needs assessment Dam Safety Report. Denver: U.S. Department of the Interior Bureau of Reclamation Dam Safety Office, 1998.

[2] Juliastuti and O. Setyandito, "Dam break analysis and flood inundation map of Krisak dam for emergency action plan," in Action Plan, AIP Conference Proceedings, 2017, p. 100005.

[3] I. . Şükrü, M. V Mohsen, and R. Emmanuel, "Emergency Action Plan for Dams Safety Application for Seyhan Dam in Adana," Fourth Natl. Symp. Dam Saf. Turkey, 2014.

[4] B. Gary, Using HEC-RAS for Dam Break Studies. Davis: Using HEC-RAS for Dam Break Studies, 2014.

[5] K. Jesper and K. Nikolaj, Interaction Design for Handheld Computers APCH. Beijing: Science Press, 2002.

[6] B. A. Tri, Pedoman Teknis Klasifikasi Bahaya Bendungan. Jakarta: Balai Bendungan, Directorate General of Water Resources, Ministry of Public Works and Housing, 2015.

[7] Widagdo, M. Joko, and Juliastuti, Dam of Indonesia, A Journey Toward National Water Security. Jakarta: Directorate General of Water Resources, Ministry of Public Works, 2014. 
[8] B. Jerry, S. C. I. John, L. N. Barry, and N. M. David, Discrete-event System Simulation. Essex: Pearson Education Limited, 2014.

[9] U. J. Dymon, “An Analysis of Emergency Map Symbology,” Int. J. Emerg. Manag., vol. 1, no. 3, pp. 227-37, 2003. 